E-ISSN: 2808-5361

http://e-journal.fkmumj.ac.id/
Proceeding The First

Muhammadiyah

Internasional- Public Health and Medicine Conference

\title{
Factors Related to Symptoms in Patients Suspect Covid-19 in The Public Health Center Kebayoran Baru in March - June 2020
}

\author{
${ }^{1}$ Tri Wahyuni, ${ }^{2}$ Suherman, ${ }^{3}$ Nazarwin Saputra, ${ }^{4}$ Istianah Surury \\ Faculty of Public Health, Muhammadiyah University of Jakarta \\ K.H. A. Dahlan, Cirendeu, Ciputat Timur, Tangerang Selatan, 15419 \\ E-mail: triwahyuni280@gmail.com
}

\begin{abstract}
The world is undergoing the new pandemic named COVID-19 of early 2020 announced in China and all over the world and infect more than 10 million people in the world (incidence rate 1.3). Indonesia has the number of cases 28.818 per June 04, 2020, with a CFR of 6\%, the highest in Southeast Asia. Besides confirming the case, the suspect like ODP, PDP, and OTG should also be monitored. Although the number of cases and suspects in the Kebayoran Baru district is not the highest in South Jakarta, as the center of South Jakarta where many offices and high mobility, and the population is not as much as another district, so the possible transmission of COVID-19 in Kebayoran Baru still high. To find out the relationship between age, sex, comorbid hypertension, diabetes mellitus, and heart disease with the severity of symptoms in COVID-19 suspect of Kebayoran Baru district MarchJune 2020. The design of this study used cross-sectional secondary data of COVID-19 suspect monitoring in Community Health Center Kebayoran Baru. Analysis with chi-square 0.005. Statistical results of COVID-19 suspects in the Kebayoran Baru district are 44\% having symptoms. The research suggests that a significant relationship between age, hypertension comorbid, diabetes mellitus comorbid, and heart disease with the symptoms. While sex has no significant relation with symptoms. The government should have more attention to protect people that having comorbid such as hypertension, diabetes mellitus, or heart disease.
\end{abstract}

Keywords: COVID-19, Suspect, Risk Factors 
E-ISSN: 2808-5361 http://e-journal.fkmumj.ac.id/
Proceeding The First

Muhammadiyah

Internasional- Public Health and Medicine Conference

\section{INTRODUCTION}

Eighteen years ago, the world had witnessed the emergence of 3 outbreaks of the deadly coronavirus, which is known to cause respiratory and digestive complications in humans. The first, severe acute respiratory syndrome caused by SARS-CoV in 2002 in Guangdong China then infected 8098 people in 37 countries. Then, another outbreak called Middle East Respiratory Syndrome caused by MERS-CoV occurred in the Middle East in 2012. Meanwhile, recently the deadliest new coronavirus members appeared in Wuhan China, spreading rapidly out of China and moving to several countries. During the first 40 days of the outbreak, the novel coronavirus (SARS-CoV-2) has caused the deaths of more than 1800 people and infected more than 75,000 people. What's more, more than 7000 people are suspect in Wuhan (Khan, et. all, 2020).

Since December 8, 2019, many cases of pneumonia with unknown causes have been reported in Wuhan, Hubei Province, China. Most patients work or live around Huanan Seafood Market, where live animals are also sold. In this early phase of pneumonia, symptoms of acute respiratory infection are common, with some patients suffering from Acute Respiratory Distress Syndrome (ADRs), acute respiratory failure, and other serious complications (WHO, 2020).

Although early studies reported a link between fish markets and wild animals with most cases indicating possible transmission from animals to humans, research shows transmission of SARS$\mathrm{CoV}-2$ from human to human through droplets or direct contact. Based on the rapidly rising incidence of infectious infections and the possibility of transmission through non-symptomatic people or carriers, SARS-CoV-2 can be transmitted between humans quickly and effectively thus demonstrating the high potential to become a pandemic in the world (Huang, C, et. all. 2020).

The number of COVID-19 cases is very fast because of its easy transmission. As of June 04, 2020 , there were $6,397,294$ confirmed cases worldwide with 383,872 deaths. The 10 countries with the highest number of cases were the United States with 1,854,476 cases, Brazil with 584,016 cases, Russia with 440,538 cases, The United Kingdom with 281,270 cases, Spain with 240,326 cases, Italy with 233,836 cases, India with 218,437 cases, France with 184,472 cases, Peru with 178,914 cases, and Turkey with 166,422 cases. Indonesia is ranked 32nd out of all countries in the world to report COVID-19 cases with 28,181 cases recorded (Jhon Hopkins University, 2020).

COVID-19 was first reported in Indonesia on March 02, 2020, as many as 2 cases, the spread of COVID-19 cases is also very fast which is even almost evenly distributed in all provinces in Indonesia. Data from 04 June 2020 shows 28.818 confirmed cases with 1721 deaths. The mortality rate in Indonesia at $6 \%$ is the highest in Southeast Asia. The provinces with the highest number of cases are DKI Jakarta, East Java, and West Java. DKI Jakarta is the province with the highest cases of Covid-29 in Indonesia with a total number of cases of 7600 as of June 04, 2020. Most cases occur in 
E-ISSN: 2808-5361

http://e-journal.fkmumj.ac.id/
Proceeding The First

Muhammadiyah

Internasional- Public Health

and Medicine Conference

the age range of 45 - 54 years and at least occur at the age of 0 - 5 years. The highest mortality rate was found in patients aged $55-64$ years (COVID-19.go.id).

Based on the results of a study of 41 COVID-19 confirmed patients through real-time PCR screening at Wuhan Hospital, more patients were male by $73 \%$, more than half of patients had concomitant diseases such as hypertension, diabetes, and cardiovascular disease. The most common symptoms experienced by respondents in the study were fever, cough, fatigue, or myalgia ((Huang, $\mathrm{C}$, et. all. 2020).

According to Rachel Pung's research, et al on the results of the investigation of 3 COVID-19 clusters in Singapore in 17 patients found the most female patients as many as 10 people and 7 male patients, with 3 chronic symptoms experienced, and the most experienced symptoms are fever and cough.

In addition to the positive confirmation cases of COVID-19 that need to be considered are also existing COVID-19 suspects, the more cases are confirmed positive, the more cases of COVID19 suspects. Based on existing studies, only $20 \%$ of infected patients and those who still need treatment in the hospital, while $80 \%$ are self-quarantined and self-isolated at home. Especially for the mild and asymptomatic suspects that are not carried out health care in hospitals because they do not have severe symptoms and still allow for self-isolation at home, but must also be monitored by local health authorities (Ministry of Health RI, 2020).

The first case of COVID-19 in Indonesia did come from Depok, but the beginning of the spread of the virus was in the South Jakarta area where the beginning of the spread of the virus came from one of the clubs in the South Jakarta area where the first COVID-19 cases in Indonesia interacted and came into contact with Japanese citizens infected with the COVID-19 virus. After tracing contact, many patients are closely connected in South Jakarta.

In March 2020 South Jakarta was the most vulnerable area to COVID-19. On March 22, 2020, the number of cases in South Jakarta was 71 cases (33\%) out of a total of 214 cases in Jakarta. Kebayoran Baru Public Health Center conducts monitoring on COVID-19 suspects starting from March 2020. Until May 2020 the number of suspects conducted monitoring is 262 people that have asymptomatic to mild symptoms. The number of suspect patients monitored by the Kebayoran Baru Public Health Center is not the highest in South Jakarta, but considering the number of residents in Kebayoran Baru Subdistrict including the least compared to other sub-districts, although the number of confirmed patients and the number of a suspect will not affect the rate of incidence rate in Kebayoran Subdistrict itself. In addition, Kebayoran Baru District is the center of South Jakarta where many offices with high mobility so the possibility of transmission is still very high. 


\section{METHODS}

The method used in this study is descriptive quantitative with cross-sectional research type to find out the relationship between age, gender, hypertension comorbid, diabetes mellitus comorbid, and cardiac comorbid with symptoms experienced by COVID-19 suspect patients at Kecamatan Kebayoran Baru Public Health Center in March - June 2020. The samples in this study are all COVID-19 suspects monitored by Kebayoran Baru Public Health Center in March - June 2020 with a total sample of 497 respondents. Data analysis using univariate and bivariate analysis.

\section{RESULTS AND DISCUSSION}

Respondents in this study were COVID-19 suspects at the Kebayoran Baru Public Health Center in March - June 2020 are 497 people. In this study, researchers wanted to see the relationship of risk factors of age, gender and hypertension, diabetes mellitus, and cardiac comorbid with symptoms experienced by COVID-19 suspect in Kebayoran Baru Public Health Center. The characteristic results of respondents can be seen in Table 1 .

Table 1 Respondent Characteristics based on Symptoms, Age, Gender, Hypertension, Diabetes Mellitus and Cardiac Comorbid

\begin{tabular}{lcc}
\hline \multicolumn{1}{c}{ Variable } & N & \% \\
\hline Symptoms & 166 & $34 \%$ \\
symptomatic & 328 & $66 \%$ \\
asymptomatic & 224 & $45 \%$ \\
\hline Gender & 273 & $55 \%$ \\
Male & & \\
Female & 57 & $12 \%$ \\
\hline Age & 440 & $88 \%$ \\
vulnerable age & & \\
Invulnerable age & 27 & $4 \%$ \\
\hline Hypertension Comorbid & 470 & $96 \%$ \\
Yes & 12 & $98 \%$ \\
No & 485 & $2 \%$ \\
\hline Diabetes Mellitus Comorbid & & \\
Yes & 10 & $2 \%$ \\
No & 487 & $98 \%$ \\
\hline Cardiac Comorbid & & \\
Yes & & \\
No & & \\
\hline
\end{tabular}

From the table, it showed that more suspects had no symptoms than those with symptoms, more suspects who were not vulnerable than those of vulnerable age, more female than male. The number of a suspect who has hypertension comorbid only 27 people (4\%), who have diabetes mellitus comorbid only 12 people (2\%) and who have cardiac comorbid only 10 people (2\%). 
Table 2 Relationship Between Age, Gender, Hypertension Comorbid, Diabetes Mellitus Comorbid and Cardiac Comorbid with Symptoms Experienced by Suspect COVID-19

\begin{tabular}{llcc}
\hline & P-Value & OR & CI (95\%) \\
\hline $\begin{array}{l}\text { Age } \\
\text { Vulnerable }(0-5 \&>60)\end{array}$ & 0.000 & 3.34 & $1.89-5.88$ \\
$\begin{array}{l}\text { Non Vulnerable (6-59) } \\
\text { Gender }\end{array}$ & & & \\
$\begin{array}{l}\text { Male } \\
\text { Female }\end{array}$ & 0.066 & 0.68 & $0.47-1.06$ \\
$\begin{array}{l}\text { Hypertension Comorbid } \\
\text { Yes }\end{array}$ & 0.000 & 5.067 & $2.16-11.8$ \\
$\begin{array}{l}\text { No } \\
\text { Diabetes Mellitus Comorbid }\end{array}$ & & & \\
$\begin{array}{l}\text { Yes } \\
\text { No } \\
\text { Cardiac Comorbid }\end{array}$ & 0.026 & 4.02 & $1.19-13.5$ \\
Yes & & & \\
No & 0.036 & 4.68 & $1.19-18.3$ \\
\hline
\end{tabular}

From the table above it is known that COVID-19 patients who have vulnerable age (toddlers and elderly) in the Kebayoran Baru Subdistrict, there are 34 (60\%) who have symptoms. While at the age of not vulnerable there are 135 (31\%) who have symptoms. The results of continuity correction statistical test obtained of $\mathrm{p}$-value $=0.000$ there is a meaningful relationship between age and symptoms experienced by COVID-19 suspect in the Kebayoran Baru Subdistrict area in 2020. The results of the analysis showed the value of Odds Ratio $=3.34$ with $95 \%$ CI $1.89-5.88$, meaning that vulnerable age has a 3.34 times chance to experience symptoms of COVID-19 compared to the age that is not vulnerable in the district of Kebayoran Baru in 2020.

The male suspect COVID-19 in the Kebayoran Baru Public Health Center, there are 66 (30\%) who have symptoms. While The female suspect COVID-19 are 103 (38\%) who have symptoms. The results of continuity correction statistical test obtained of $p$-value $=0.066$ means there is no meaningful relationship between the sexes and the symptoms experienced by the COVID-19 suspect in the Kebayoran Baru Public Health Center in 2020.

COVID-19 suspects who have hypertension comorbid in the Kebayoran Baru Public Health Center, there are $19(70 \%)$ who have symptoms. While in those who do not have a history of hypertension comorbid are 150 (32\%) who have symptoms. Statistic continuity correction test results obtained of $\mathrm{p}$-value $=0.000$ means there is a meaningful relationship between hypertension comorbid and symptoms experienced by COVID-19 suspect in the Kebayoran Baru Public Health Center in 2020. The results of the analysis showed the value of Odds Ratio $=5,067$, meaning that hypertension comorbid has a 5 times chance to experience symptoms of COVID-19 compared to those who do not have hypertension comorbid in the district of Kebayoran Baru in 2020.

COVID-19 suspects who have diabetes mellitus comorbid in the Kebayoran Baru Public Health Center, there are $8(67 \%)$ who have symptoms. While those who do not have diabetes mellitus 
E-ISSN: 2808-5361 http://e-journal.fkmumj.ac.id/
Proceeding The First

Muhammadiyah

Internasional- Public Health and Medicine Conference

comorbid are 161 (33\%) who have symptoms. Fisher's Exact Test results obtained of p-value $=0.026$ so that means there is a meaningful relationship between the diabetes mellitus comorbid and the symptoms. The results of the analysis showed the value of Odds Ratio $=4.02$, meaning that diabetes mellitus comorbid has a 4 times chance to experience symptoms of COVID-19 compared to those who do not have comorbid diabetes mellitus in the district of Kebayoran Baru in 2020.

COVID-19 suspects who have cardiac comorbid in the Kebayoran Baru Public Health Center, there are 7 (70\%) who have symptoms. While those who do not have cardiac comorbid are $3(30 \%)$ who have symptoms. Fisher's Exact Test test results obtained a value of $\mathrm{p}$-value $=0.036$ so that means there is a meaningful relationship between cardiac comorbid and symptoms by COVID-19 suspects in the Kebayoran Baru Public Health Center in 2020. The results of the analysis showed the value of Odds Ratio $=4.68$, meaning that the cardiac comorbid has almost 5 times the chance to have symptoms of COVID-19 compared to those who do not have cardiac comorbid in the Kebayoran Baru Public Health Center in 2020.

COVID-19 outbreaks in the Kebayoran Baru Public Health Center are more severely asymptomatic than those with symptoms. This is because in Public Health Center that is monitored are COVID-19 patients who do not have symptoms or mild symptoms instead of severe symptoms because those who have severe symptoms require treatment so usually send to the hospital.

The symptoms of COVID-19 patients are very important because it determines the type of treatment and medical measures. If the symptoms of the patient or COVID-19 suspect are mild or even asymptomatic symptoms can be self-isolation at home and monitored by the Public Health Center if the state of the house allows for self-isolation, thus the patient does not need hospital treatment to reduce the burden of hospitals and health workers. Hospitals can focus more on treating patients who have more severe symptoms and need regular health monitoring.

The results of this study are in line with a press release from a government spokesman on the handling of COVID-19 Achmad Yurianto dated 07 June 2020 saying that $80 \%$ of positive cases of COVID-19 in Indonesia are found in people who show no symptoms at all. According to WHO, most (about 80\%) infected people recover without the need for special treatment. About 4 out of 5 people infected with COVID-19 are asymptomatic or experience mild symptoms.

Report from the China National Health Commission on 01 April 2020130 of the 166 confirmed cases of new COVID-19 are asymptomatic.

Based on Mizumoto K research, et al (2020) in the case of COVID-19 Diamond Princess Cruise ship quarantined in Yokohama Japan found 328 cases of COVID-19 confirmation without symptoms. From the results of statistical modeling obtained the proportion of asymptomatic patients is $17.9 \%$ (95\% CI: $15.5-20.2)$. 
E-ISSN: 2808-5361 http://e-journal.fkmumj.ac.id/
Proceeding The First

Muhammadiyah

Internasional- Public Health and Medicine Conference

In this study, the most common symptoms were cough, fever, cold, and shortness of breath. This is in line with the data on the website COVID19.go.id that the common symptoms suffered by COVID-19 patients in Indonesia are coughs, fevers, shortness of breath, weakness, and colds.

According to WHO (2020), the symptoms of COVID-19 patients have a wide spectrum, ranging from asymptomatic, mild symptoms, pneumonia, severe pneumonia, ARDS, sepsis, to sepsis shock. Most people with COVID-19 have mild symptoms (40\%) or moderate symptoms (40\%), 15\% need oxygen support, and 5\% have severe symptoms with complications such as ARDS respiratory failure, sepsis, and septic shock, thromboembolism, multiorgan failure including kidney failure and heart failure. Most patients infected with SARS-CoV-2 show symptoms in the respiratory system such as fever, cough, sneezing, and shortness of breath. Based on data from 55,924 cases, the most common symptoms are fever, dry cough, and fatigue.

According to Chen's research, et al (2020) in 249 patients in Shanghai China, the most common symptoms experienced by COVID-19 confirmed patients were fever as much as $87.1 \%$ and cough as much as 36.5\%. In line with Wang D's research, et al (2020) in 138 hospital patients in Wuhan, China the most common symptoms experienced by patients were fever as much as $98.6 \%$, weakness as much as $69.6 \%$, and cough as much as $59.4 \%$.

The suspect of COVID-19 in Kebayoran Baru Public Health Center more are not vulnerable (6-59 years old) age than vulnerable people (toddlers and elderly). This is in line with the data on the website Covid19.go.id that in Indonesia the most affected by COVID-19 is the productive age of 18 59 years, this is because people who are of productive age do more activities and mobility outside the home is quite high than those over 60 years of age thus increasing the risk of exposure to COVID-19.

Young people are generally more or less careful to interact with others or leave the house because they feel healthy and will not infect COVID-19 compared to the elderly so that young/productive age has more potential to infect COVID-19 than those who are vulnerable age because of this.

According to a CDC report in March 2020, more COVID-19 patients aged 18 - 64 years old are reported in the United States. The report is in line with the results of this study.

This is in line with Guan $\mathrm{Wj}$, et al(2020) research from 575 COVID-19 patients in 31 provinces of China, the average age of COVID-19 patients is 48.9 years.

Boddington NL, et al (2020) research on the first 100 COVID-19 patients in the UK found the average age affected by COVID-19 was 47.7 years.

The gender proportion of COVID-19 suspects in the Kebayoran Baru sub-district is more female than that of men, although the difference is not very significant at only $10 \%$. 
E-ISSN: 2808-5361

http://e-journal.fkmumj.ac.id/
Proceeding The First

Muhammadiyah

Internasional- Public Health and Medicine Conference

The results of this study are different from Indonesia's COVID-19 data where more COVID19 patients are male than female. Similarly, COVID-19 patient data in DKI Jakarta is also more dominated by men than women.

Similarly, Boddington NL research, et al (2020) in the first 100 COVID-19 patients in the UK also found more patients of male sex than women.

However, based on Korean CDC data on the first 7,755 COVID-19 patients in South Korea, there are more female patients than men.

In various studies that are still running until now more COVID-19 patients are male than female because men are more active outside the home and the level of mobility is higher than women.

However, in this study, more COVID-19 patients were female than men. This is because the object of this study is that covid-19 is still not a confirmed patient of COVID-19 so it still allows a lot of data bias in sampling.

Hypertension or high blood pressure is a condition where systolic blood pressure $\geq 140 \mathrm{mmHg}$ and or diastolic blood pressure $\geq 90 \mathrm{mmHg}$, often referred to as The Silent Killer because it is often without symptoms (Ministry of Health Indonesia, 2019).

Heart and vascular disease (cardiovascular) is the main health problem in developing countries and is the number one cause of death in the world every year. Hypertension is one of the most common cardiovascular diseases and is most widely carried by the public. WHO data in 2015 showed about 1.13 billion people worldwide have hypertension, meaning 1 in 3 people in the world is diagnosed with hypertension. The number of people with hypertension continues to increase every year, it is estimated that by 2025 there will be 1.5 billion people affected by hypertension and it is estimated that every year 10.44 million people die from hypertension and complications (Ministry of Health, 2019).

Basic Health Research Data in 2018 stated the prevalence of hypertension based on the results of measurements in the population of $\geq 18$ years of age of $34.1 \%$, the estimated number of hypertension cases in Indonesia is 63.3 million people, while the death rate in Indonesia due to hypertension is 427,218 people. From the data, it is known that the trend of hypertension has increased at a younger age, about $31.6 \%$ of the 31 - 44 years old age group has hypertension (Riskesdas, 2018).

In this study, it was known that in 497 COVID-19 patients in Kebayoran Baru Public Health Center who have hypertension comorbid are 27 people (4\%). In various studies that are still ongoing until now, the number of hypertensive comorbid in confirmed cases of COVID-19 varies in prevalence.

From the results of the study, known that the comorbid most suffered by COVID-19 patients in Kecamatan Kebayoran Baru Public Health Center is hypertension compared to other comorbid. 
E-ISSN: 2808-5361 http://e-journal.fkmumj.ac.id/
Proceeding The First

Muhammadiyah

Internasional- Public Health and Medicine Conference

This is because the data of the annual report of the Kebayoran Baru Public Health Center in 2018 that from the list of the 10 most diseases in the Kebayoran Baru Public Health Center the highest number 2 is hypertension as many as 9,220 patients.

Meanwhile, based on the China CDC report, COVID-19 confirmed patient data as of February 11, 2020, in China, 2,683 (12.8\%) of the 72,314 people confirmed by COVID-19 have comorbid hypertension.

Based on the U.S. CDC report, COVID-19 confirmed patient data for the period March - June 2020, it is known that out of the 350 patients studied there were 97 people (29\%) who have comorbid hypertension.

From the results of Nikpouradhdam M, et al (2020) it is known that out of 2,964 confirmed cases of COVID-19 in Iran, there were 59 people (1.99\%) who have comorbid hypertension.

Diabetes Mellitus is a serious chronic disease that occurs because the pancreas does not produce enough insulin (a hormone that regulates blood sugar or glucose) or when the body can effectively use the insulin it produces. Diabetes is an important public health issue, being one of four priority non-communicable diseases targeted by world leaders. The number of cases and prevalence of diabetes has continued to increase over the last few decades (WHO Global Report 2016 in the Ministry of Health, 2019).

Globally, an estimated 422 million adults lived with diabetes in 2014, compared with 108 million in 1980. The prevalence of diabetes in the world (with a standardized age) has almost doubled since 1980, increasing from $4.7 \%$ to $8.5 \%$ in the adult population. Diabetes caused 1.5 million deaths in 2012. Higher blood sugar than the maximum limit resulted in an additional 2.2 million deaths by increasing the risk of cardiovascular and other diseases. $43 \%$ of these 3.7 million deaths occur before the age of 70 . The percentage of deaths caused by diabetes that occur before the age of 70 is higher in low- and middle-income countries than in high-income countries (WHO Global Report 2016 in the Ministry of Health, 2019).

In this study is known that in 497 COVID-19 patients in Kebayoran Baru Public Health Center who have diabetes mellitus comorbid are 12 people (2\%). In various studies that are still ongoing until now, the number of diabetes mellitus comorbid in confirmed cases of COVID-19 varies in prevalence.

From the results of the study, it is known that the number of people with diabetes mellitus in a covid-19 suspect in Kebayoran Baru Public Health Center includes only 2\%. This is because this study is only based on secondary data, not conducted interviews and blood sugar measurement directly against the suspect or seen from the patient's medical record. This results in the bias of information from the data obtained. 
E-ISSN: 2808-5361 http://e-journal.fkmumj.ac.id/
Proceeding The First

Muhammadiyah

Internasional- Public Health and Medicine Conference

According to a Korean CDC report (2020) on the first 7755 patients confirmed by COVID-19 in South Korea only $0.2 \%$ of South Koreans confirmed to have COVID-19 have diabetes mellitus comorbid.

Based on the U.S. CDC report, COVID-19 confirmed patient data from January 22 to May 30, 2020 , there were 86,737 people (30.2\%) with diabetes from 1,320,488 confirmed cases of COVID-19.

Every year more than 36 million people die from Non-Communicable Diseases (63\%) of all deaths). More than 9 million deaths caused by Non-Communicable Diseases occur before the age of 60 years, and $90 \%$ of these premature deaths occur in low- and middle-income countries (Ministry of Health, 2014).

Globally non-communicable diseases the number one cause of death each year is cardiovascular disease. Cardiovascular disease is a disease caused by impaired heart and blood vessel function. Heart disease is a disorder of heart function due to the heart muscle's lack of blood due to blockage or narrowing of blood vessels due to damage to the lining of the walls of blood vessels (Ministry of Health RI, 2014).

Based on the results of this study, it is known that out of 497 COVID-19 outbreaks in the Kebayoran Baru Sub-District in March - June 2020 there were 10 people (2\%) that have a cardiac comorbid.

From the results of the study, it was seen that the prevalence of COVID-19 outbreaks in Kebayoran Baru Public Health Center that has cardiac comorbid is included a little. This is because the research was conducted using secondary data instead of through interviews directly on a suspect or taking patient medical record data so that the possibility of information bias at the time of data retrieval can occur. In addition, monitoring of COVID-19 suspects by surveillance personnel of Kebayoran Baru Public Health Center is conducted by phone / WhatsApp so that information bias at the time of epidemiological investigation can be very happening. Moreover, many people in Indonesia do not do regular health check-ups so do not know their health condition thoroughly including heart health.

According to Boddington NL research, et al (2020) in the first 358 confirmed COVID-19 in the UK there were 17 people (4.7\%) who suffers from heart disease.

Meanwhile, based on the China CDC report, COVID-19 confirmed patient data as of February 11, 2020, in China, as many as $873(4.2 \%)$ of the 72,314 people confirmed by COVID-19 have comorbid cardiovascular disease.

Based on the U.S. CDC report, COVID-19 confirmed patient data from January 22 to May 30, 2020 , there were 92,546 people $(32.2 \%$ ) cardiovascular disease out of $1,320,488$ confirmed cases of COVID-19. 
E-ISSN: 2808-5361 http://e-journal.fkmumj.ac.id/
Proceeding The First

Muhammadiyah

Internasional- Public Health and Medicine Conference

From some of the research literature, it is confirmed that COVID-19 confirmed people who have heart comorbid are not too many ranging from $0.1 \%-4.7 \%$, except from the U.S. CDC report of $32.2 \%$, it is known that in the United States many of its citizens suffer from obesity and diabetes mellitus so the possibility of having comorbid heart disease is very possible.

From the results of the study, it is known that COVID-19 patients who have a vulnerable age in the Kebayoran Baru Public Health Center, there are as many as 34 (60\%) who have symptoms. While at the age of not vulnerable as much as $135(31 \%)$ have symptoms. The results of continuity correction statistical test obtained of $\mathrm{p}$-value $=0.00$, that means there is a meaningful relationship between age and symptoms by COVID-19 suspect in the Kebayoran Baru Public Health Center in 2020. The results of the analysis showed the value of Odds Ratio $=3.34$ with 95\% CI $1.89-5.88$, meaning that vulnerable age has a 3.34 times chance to experience symptoms of COVID-19 compared to the age that is not vulnerable

Based on data COVID19.go.id in Indonesia the highest rate of death from COVID-19 infection occurs in the elderly over 60 years as much as $40 \%$.

This study is in line with the results of a study in Pavia, Northern Italy on 21 - 28 February 2020 in 44 patients found more patients treated aged $>65$ years with OR 0.043 and p-value 0.012 (Colaneri M, et al., 2020).

This study is also in line with the research of Lian J, et al (2020) in patients over the age of 60 and under 60 years outside Wuhan obtained the results that patients over the age of 60 years have severe symptoms / critical compared to those under 60 years old with a value of P-value of $<00,001$.

Until now, deaths and severe symptoms have been common in covid-19 patients over the age of 60 . With age, the body will experience various decreases due to the aging process ranging from decreased production of hair color pigments, hormone production, skin suppleness, muscle mass, bone density, tooth strength to the function of body organs. The immune system as a body protector does not work as strongly as when young, as a result, it is difficult for the elderly to fight various bacteria and viruses that enter the body. This is why elderly people are susceptible to various diseases, including COVID-19.

In addition, not a few elderly people have chronic diseases such as diabetes, heart disease, or hypertension. This can result in a 2-fold risk for the elderly when infected with the coronavirus. The risk of complications arising from COVID-19 can be more severe for sufferers if they already have the disease because this coronavirus infection can decrease the function of other organs so that the chronic disease condition that has been experienced by sufferers will get worse and can even cause death.

From the study is known that there is 66 male COVID-19 suspect who has symptoms. While female COVID-19 suspects are 103 (38\%) who have symptoms. The results of the continuity 
E-ISSN: 2808-5361 http://e-journal.fkmumj.ac.id/
Proceeding The First

Muhammadiyah

Internasional- Public Health and Medicine Conference

correction statistical test obtained of p-value $=0.066$ means that there is no meaningful relationship between gender and symptoms experienced by COVID-19 suspects.

Based on data on the website Covid19.go.id covid-19 confirmed people in Indonesia more men than women, although the difference is not very significant only $10 \%$.

This study is in line with Tenforde MW, et al (2020) research published by CDC Weekly Report found that in the United States more COVID-19 patients are hospitalized than men with a proportion of $53 \%$ and p-value of 0.85 , meaning there is no relationship between gender and hospital care in COVID-19 confirmed people in the United States.

This study is also in line with the results of Sun Y, et al (2020) study on 788 subjects of COVID-19 confirmed patients in Singapore, it was found that there was no relationship between gender and clinical symptoms with a p-value of 0.488 .

However, this study is not in line with nikpouraghdam M, et al (2020) research in 12,870 patients at Baqitallah Hospital Tehran Iran found that men are a risk factor for having severe clinical symptoms of COVID-19 compared to women with OR values of $1.45,95 \%$ CI: $1.08-1.96$. This study is different because the design of the study in nikpouraghdam research uses a retrospective cohort study while this study using cross-sectional so that the results are different.

Based on literature from WHO states that men have risk factors for experiencing symptoms of COVID-19 infection that are more severe than those of the female gender. However, until now in various studies have different results.

Men are more susceptible to having more severe symptoms of COVID-19 than women because men have higher mobility than women, men as the backbone of the family who have to make a living then have to leave the house which can increase the risk of developing COVID-19 compared to women.

In addition, more men smoke than women so men have risk factors for having more severe symptoms of COVID-19 infection than women. Because cigarettes increase the concentration of ACE2 receptor cells in the lungs, where the COVID-19 virus enters the body cells through ACE2 so that if the ACE2 receptors in the lungs are more then the symptoms of lung damage will be more severe due to more viral infections.

In this study, more women than men, because the object of this study is still the status of COVID-19 suspect, is not a confirmed patient of COVID-19 so it still allows a lot of data bias in sampling. In addition, the population in the district of Kebayoran Baru is also more female than male, thus allowing it to affect the results of this study.

From the results of the study, it is known that COVID-19 suspects who have hypertensive comorbidity are $19(70 \%)$ who have symptoms. While in those who do not have a history of hypertension are $150(32 \%)$ who have symptoms. The results of continuity correction statistical test 
E-ISSN: 2808-5361 http://e-journal.fkmumj.ac.id/
Proceeding The First

Muhammadiyah

Internasional- Public Health and Medicine Conference

obtained p-value $=0.000$ means that there is a meaningful relationship between hypertension comorbid and symptoms experienced by COVID-19 suspect. The results of the analysis showed the value of Odds Ratio = 5,067 with 95\% CI $2.16-11.8$, meaning that hypertension comorbid has a 5 times chance to experience symptoms of COVID-19 compared to those who do not have hypertension comorbid.

This study is also in line with Stanford MW, et al (2020) research published by CDC Weekly Report found that there is a meaningful relationship between hypertensive comorbid and hospital care in COVID-19 confirmed people in the United States with a p-value of 0.023.

This study is also in line with Guan WJ, et al (2020) research on 1590 COVID-19 patients from 575 hospitals in 31 provinces in China are 269 patients (16.9\%) have comorbid hypertension. People who had comorbid hypertension had 1.58 times (95\%CI: $1.07-2.32$ ) greater risk of having severe symptoms than those who did not have hypertension comorbid.

Based on the data on the website Covid19.go.id hypertension is the most comorbid that is seen by people confirmed by COVID-19 in Indonesia.

SARS-CoV-2 enters the body's cells and replicates through ACE2. Some research suggests that administration of antihypertensive drugs such as ACE inhibitors (ACEis) and Angiotensin receptor blockers (ARBs) may be associated with an increase in ACE2 in surface cells, thus ultimately supplying SARS-CoV-2 with greater amounts to infect cells. People who have hypertension have smaller renin-angiotensin-aldosterone than those who do not have comorbid hypertension in producing ACE2 cells making them more susceptible to SARS-CoV-2 infections that ultimately increase the severity of symptoms and cytokine storms in the body that could cause ADRs.

From the results of the study, it is known that COVID-19 suspects who have diabetes mellitus comorbid are $8(67 \%)$ who have symptoms. While those who do not have diabetes mellitus comorbid are $161(33 \%)$ who have symptoms. Fisher's Exact Test statistical test results obtained p-value = 0.026 means there is a meaningful relationship between the diabetes mellitus comorbid and the symptoms COVID-19 suspect. The results of the analysis showed the value of Odds Ratio $=4.02$ with 95\% CI 1.19 - 13.5, meaning that comorbid diabetes mellitus has a 4 times chance to experience symptoms of COVID-19 compared to those who do not have comorbid diabetes mellitus.

This study is also in line with Boddington NL, et al (2020) research on the first 358 CONFIRMED COVID-19 patients in the UK, found that people who have comorbid diabetes mellitus have a risk factor 1.41 times to experience symptoms of severe COVID-19 infection with $95 \% \mathrm{CI}$ : $1.00-2.00)$.

This study is also in line with the research of Lian J, et al (2020) in the subjects of COVID-19 confirmed patients outside Wuhan, it was obtained that there is a meaningful relationship between comorbid diabetes mellitus with severe/critical symptoms with a value of $p$-value $<0,001$. 
E-ISSN: 2808-5361

http://e-journal.fkmumj.ac.id/
Proceeding The First

Muhammadiyah

Internasional- Public Health and Medicine Conference

Uncontrolled diabetes can cause weakness of the immune system and damage to various organs. Unstable blood sugar levels can increase the risk of complications in diabetic patients. This makes diabetics more susceptible to COVID-19 and fatal complications due to coronavirus infection.

In addition, coronavirus infection is also seen to increase the risk of dangerous complications from diabetics, such as diabetic ketoacidosis and sepsis. The condition makes it more difficult for diabetic patients to fight infections, and if cured requires a longer recovery time. Various complications of diabetes can increase the risk of death from COVID-19 in diabetics.

From the results of the study, it is known that COVID-19 suspects who have cardiac comorbid are 7 (70\%) who have symptoms. While those who do not have cardiac comorbid are 3 (30\%) who have symptoms. Fisher's Exact Test statistical test results obtained p-value $=0.036$ means there is a meaningful relationship between cardiac comorbid and symptoms by COVID-19 suspect. The results of the analysis showed the value of Odds Ratio $=4.68$ with 95\% CI $1.19-18.3$, meaning that the cardiac comorbid has almost 5 times the chance to experience symptoms of COVID-19 compared to those who do not have cardiac.

This study is in line with the results of Mehra MR, et al (2020) research in 169 hospitals in Asia, Europe, and North America found 8910 COVID-19 patients, $11.3 \%$ of patients had a history of coroner's heart disease, a history of heart failure by $2.1 \%$, and $3.4 \%$ had a history of arrhythmias. People who had coroner's heart comorbid had a risk factor 2.7 times more likely to have severe symptoms than those who did not have a coroner's heart comorbid, patients who had a history of heart failure had a 2.48 times greater risk factor for having severe symptoms than those who had no history of heart failure, patients who had arrhythmia had a 1.95 times greater risk factor for having severe symptoms than those who did not experience.

This study is also in line with tenforde MW, et al (2020) research published by CDC Weekly Report found that there is a meaningful relationship between cardiac comorbid and hospital care in COVID-19 confirmed people in the United States with a p-value of 0.037.

Patients who have a long history of heart disease have a high-risk factor for developing severe symptoms during acute infection, which has been proven previously in clinical studies of influenza. Heart disease can increase the severity of symptoms and acute heart inflammation triggered by a COVID-19 virus infection that triggers injury or myocardial infarction. Cytokine storms that occur in the body of patients with cardiac comorbid during systemic inflammatory inflammation can cause instability and atherosclerotic merukak (Bonow RO, et al., 2020).

In heart patients, there is an abnormality in the structure and function/strength of the heart. Without COVID-19 infection, the patient's physical ability has decreased characterized by symptoms of chest pain and shortness of breath. An unhealthy heart cannot meet normal daily metabolic needs. 
E-ISSN: 2808-5361

http://e-journal.fkmumj.ac.id/
Proceeding The First

Muhammadiyah

Internasional- Public Health and Medicine Conference

In a state of corona infection, fever causes increased metabolism, increased oxygen demand, coughing and the production of airway mucus make the body more tired. Initially, stable heart patients can show signs of worsening. As a result, healing is more difficult and the risk of death is higher. The SARS-CoV-2 virus enters the cells through ace 2 receptors where they are present in the heart organs and the endothelial lining of blood vessels. So it triggers the virus more easily into the body's cells and replicates.

\section{CONCLUSION}

Based on the results of the study can be concluded that age, hypertension comorbid, diabetes mellitus comorbid, and cardiac comorbid have a relationship with the symptoms in the suspect COVID-19, while the sex is not related to the symptoms experienced by the suspect COVID-19 in the Kebayoran Baru Public Health Center.

\section{REFERENCES}

1. Khan, S, et al. 2020. 'The spread of novel coronavirus has created an alarming situation worldwide', Journal of Infection and Public Health 13 (2020), pp. 469 - 471. DOI: 10.1016/j.jiph.2020.03.005.

2. Chen, N, et all. 2020. 'Epidemiological and clinical characteristics of 99 cases of 2019 novel coronavirus pneumonia in Wuhan, China: a descriptive study, The Lancet Journal Vol 395, pp. 507 - 513. DOI: 10.1016/ S0140-6736(20)30211-7.

3. Zhou, F, et all. 2020. 'Clinical course and risk factors for mortality of adults-inpatients with COVID-19 in Wuhan, China: a retrospective cohort study, The Lancet Journal Vol 395, pp. 1054 - 1062. DOI: 10.1016/ S0140-6736(20)30566-3.

4. Huang, C, et al. 2020. 'Clinical features of patients infected with 2019 novel coronavirus in Wuhan, China', The Lancet Journal Vol 395, pp. 497 - 506. DOI: 10.1016/ S01406736(20)30183-5.

5. Keputusan Menteri Kesehatan Republik Indonesia Nomor HK.01.07/MENKES/413/2020 Pedoman Pencegahan dan Pengendalian Coronavirus Disease 2019 (COVID-19). Juli, 132020. Indonesia Ministry of Health. Jakarta.

6. World Health Organization. 2020. WHO coronavirus disease (COVID-19) dashboard. Available on covid19.who.int

7. Jhon Hopkins University. 2020. COVID-19 dashboard by the Center for System Science and Engineering (CSSE) at Jhon Hopkins University. Available on coronavirus.jhu.edu/map.html

8. Direktorat Jenderal Pencegahan dan Pengendalian Penyakit Kementerian Kesehatan RI. 2020. Pedoman pencegahan dan pengendalian corona virus disease 2019 (COVID-19) revisi keempat. Indonesia Ministry of Health. Jakarta. 
9. DKI Jakarta. Data Pemantauan COVID-19 DKI Jakarta. Available on corona.jakarta.go.id

10. Pung, R, et all. 2020. 'Investigation of three clusters of COVID-19 in Singapore: implications for surveillance and response measure', The Lancet Journal Vol 395. DOI: 10/1016/S01406736(20)30528-6.

11. Colaneri, M, et all. 2020. 'Clinical characteristics of coronavirus disease (COVID-19) early findings from a teaching hospital in Pavia, North Italy, 21 to 28 February 2020', Euro Surveillance 25(16). DOI: 10.2807/1560-7917.

12. Lian, J, et all. 2020. 'Analysis of epidemiological and clinical features in older patients with coronavirus disease 2019 (COVID-19) outside Wuhan', Clinical Infectious Disease Journal Vol 71. pp. 740 - 747. DOI: $10.1093 / \mathrm{cid} / \mathrm{ciaa} 242$.

13. Tenforde, MW, et all. 2020. 'Characteristics of adult outpatients and inpatients with COVID-19 - 11 academic medical center, United States, March-May 2020', Morbidity and Mortality Weekly Report CDC United States of America July 03, 2020, Vol 69 No 26. Atlanta Georgia.

14. Lippi, G, et all. 2020. 'Hypertension and its severity or mortality in Corona Virus Disease 2019 (COVID-19): a pooled analysis, Polish Archives of Internal Medicine.

15. Mantovani, A, et all. 2020. 'Diabetes as a risk factor for greater COVID-19 severity and inhospital; death: a meta-analysis of observational studies, Nutrition, Metabolism, and Cardiovascular Disease Journal Elsevier. pp. 1236 - 1248. DOI: 10.1016/j.numecd.2020.05.014.

16. Zhu, L, et all. 2020. 'Association of blood glucose control and outcomes in patients with COVID-19 and pre-existing type 2 Diabetes', Cell Metabolism. pp. 1068 - 1077. DOI: 10.1016/j.cmet.2020.04.021.

17. Bonow, RO, et all. 2020. Association of coronavirus disease 2019 (COVID-19) with myocardial injury and mortality, Journal of American Medical Association Cardiology. pp. 751 - 753. DOI: 10.1001/jamacardio.2020.1105.

18. Mehra, MR, et all. 2020. 'Cardiovascular disease, drug therapy and mortality in COVID-19', The New England Journal of Medicine. DOI: 10.1056/NEJMoa2007621.

19. Shi, S, et all. 2020. 'Association of cardiac injury with mortality in hospitalized patients with COVID-19 in Wuhan, China', Journal of American Medical Association. pp. 802 - 810. DOI: 10.1001/jamacardio.202 